\title{
Window impression technique for a single denture with maxillary anterior flabby ridge
}

\author{
Muhammad Ikbal, ${ }^{*}$ Irfan Dammar, Acing Habibie Mude, Andi Adytha MIR
}

Department of Prosthodontics, Faculty of Dentistry, Hasanuddin University, Makassar, Indonesia

${ }^{*}$ Correspondence to:

ikbal_fkguh@yahoo.com

Received: 5 February 2019 Revised: 27 February 2019 Accepted: 10 March 2019 Available Online: 1 May 2019

\section{Abstract}

Objective: The aims to explain the window impression technique for a single denture with flabby tissue area in maxillary anterior ridge in the form of case report.

Methods: The clinical examination showed the maxillary complete edentulous ridge with flabby ridge area in the maxillary anterior region opposing the anterior natural teeth in the mandibular.
Results: There were various impression techniques used in the management of flabby tissue in the maxillary anterior ridge for a single denture cases.

Conclusion: The window impression technique is one of the proper techniques used in the management of flabby tissue for the single denture impression.

Keywords: Anterior ridge, Flabby ridge, Single denture

Cite this Article: Ikbal M, Dammar I, Mude AH, MIR AA. 2019. Window impression technique for a single denture with maxillary anterior flabby ridge. Journal of Case Reports in Dental Medicine. 1(2): 40-42.

\section{Introduction}

A long-term denture wearers commonly showed the hyperplastic growth of tissue that usually called as flabby tissue. ${ }^{1}$ This displaceable ridge will present some difficulties for impression and looseness related to the denture which rest on it. ${ }^{2}$ The flabby ridge was occur as a result of the using of single denture, where the mandibular anterior teeth opposing a maxillary complete denture. This relationship aggravated by an improper posterior occlusal support. Various impression technique have been described to overcome this problem. Osborne and Liddlelow described the technique that used two separate impression materials while Watson used a custom tray with a window technique which opening the flabby tissues area. ${ }^{3}$ This article aims to explain the window impression technique for a single denture with flabby tissue area in maxillary anterior ridge in the form of case report.

\section{Case Report}

A 64-years old male patient visited Dental Hospital Hasanuddin University with a loose-fitting single denture. He has been using it for about ten years. He brought his old denture and wanted to make a new one. The clinical examination showed the maxillary complete edentulous ridge with flabby ridge area in the maxillary anterior region figure $1 \mathrm{~A}$ and figure $1 \mathrm{~B}$ opposing the anterior natural teeth in the mandibular.

The treatment began with preliminary impression with alginate hydrocolloid impression material to get the study model. The flabby area first marked with tissue marker before the impression materials contact to maxillary mucosa, so that the area which must be freed from pressure would be printed on the alginate figure 2 .

After that, individual tray was made with hole space in the flabby area. The mucofunctional impression were done using greenstick compound that was applied to the edges of the individual tray. The cover tray was then installed and marked so that its position remain stable at the time of installation when impressing. These marks were made on the right and left sidesof a line which crosses from the tray through the cover tray figure 3.

The final impression was made of two separated impression materials, they were medium body and light body. The medium body firstly applied to the tray and inserted into the mouth, and the light body applied with a syringe afterward figure $4 \mathrm{~A}$. The window part of the tray was then covered with the cover tray, so that the light body material was applied lightly to the mucosa figure $4 \mathrm{~B}$. Final impression result can be seen in figure 5 . The flabby ridge area in the anterior part of maxilla is shown by the light body material in orange area, which is surrounded by the medium body material in blue area figure 5 .

\section{Discussion}

There were various impression techniques used in the management of flabby tissue in the maxillary anterior ridge for a single denture cases. 


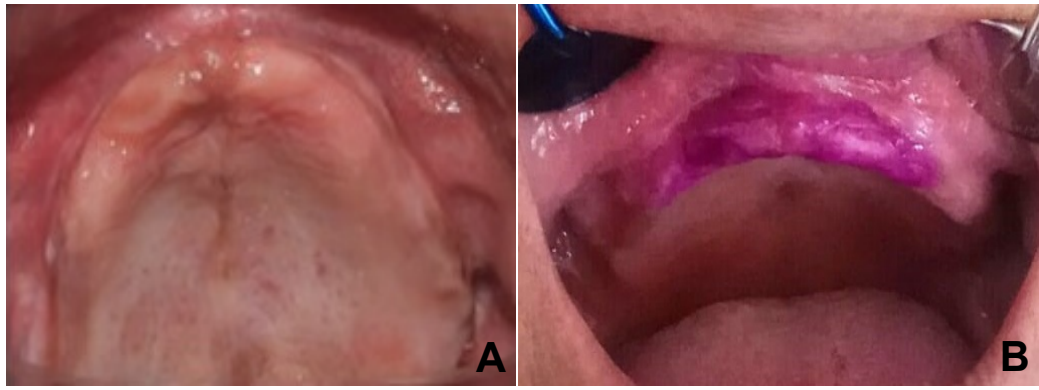

Figure 1 A. Occlusal aspect of upper jaw, B. Flabby area that has been marked with tissue marker

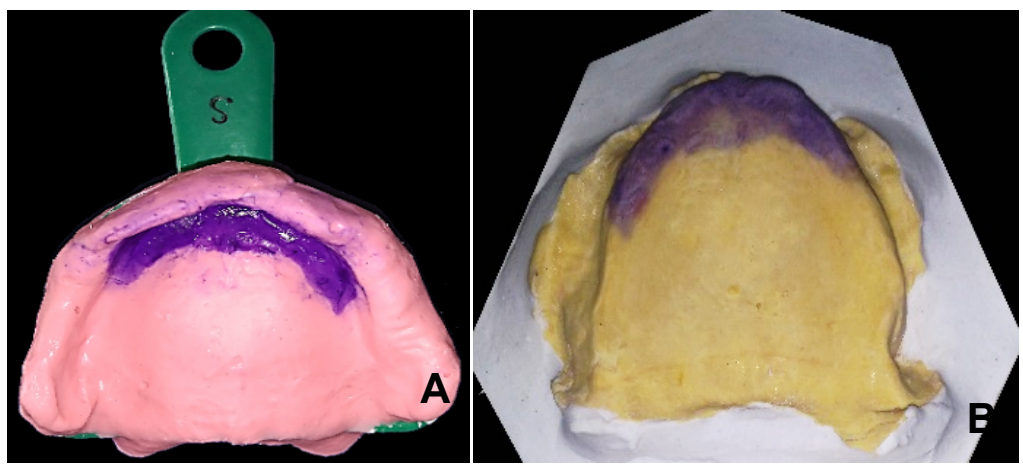

Figure 2 A. The preliminary impression with alginate, B. Study model

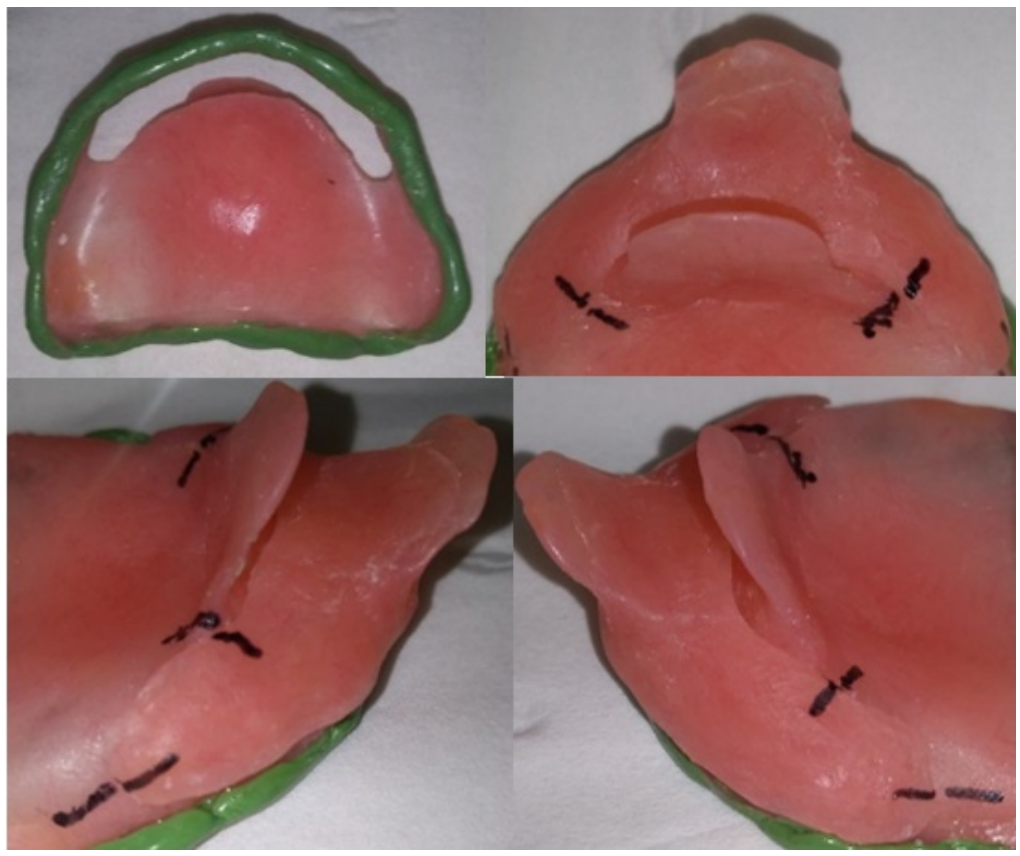

Figure 3 The marked individual tray

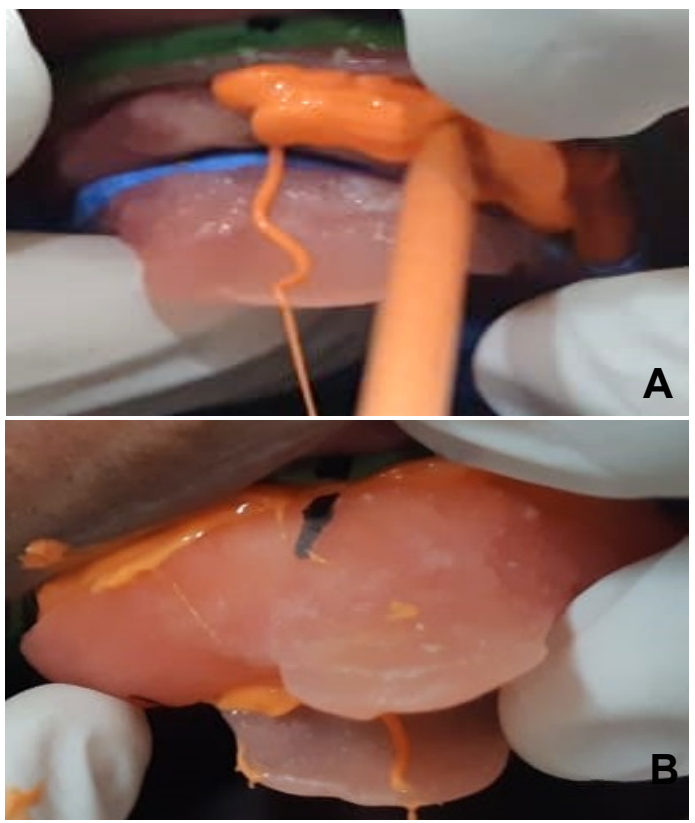

Figure 4 A.Second impression material applied, $B$. The cover tray closed the window part of the individual tray

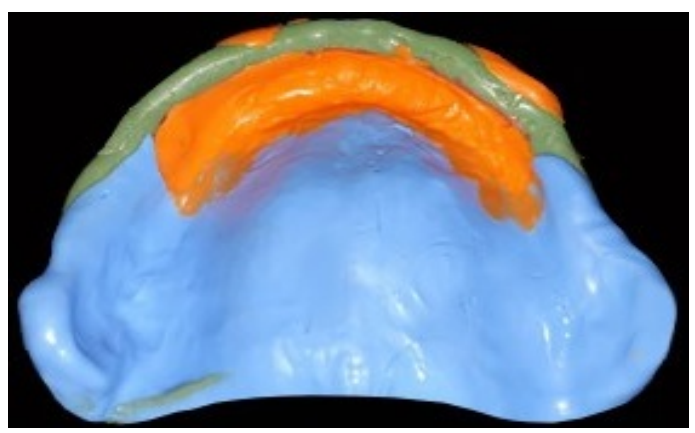

\section{Figure 4 Final impression result}

The Hobkirk's technique used the window technique impression with medium body impression material for the un-displaceable tissue whereas the flabby tissue impressed with light body elastomeric impression material. ${ }^{4}$

Another impression technique that explained by Massad had been used to obtain a final impression in a single visit using a stock tray. The tissue stops and the border molding area was done by using a putty impression material for both maxilla and mandibular. The final impression was made using light body impression material. ${ }^{4}$

Window impression technique was also proposed by Watson in order to minimize the flabby ridge movement during function. This technique used zinc-oxide-eugenol impression paste for the healthy tissue area while the impression plaster used for the flabby ridge area. ${ }^{5-}$ 
Osborne described the window impression technique as a mucocompressive impression with ZOE impression paste using a custom tray and the low viscosity impression plaster then painted through the window onto the flabby tissue. ${ }^{6}$

\section{Conclusion}

The window impression technique is one of the proper techniques used in the management of flabby tissue for the single denture impression. Many improvement can be done to provide better impression results.

\section{Aknowledgment}

I would like to thank all the Lecturer Departement of Prosthodontics Faculty of Dentistry Hasanuddin University for guiding and helping me until the completion of this article.

\section{Conflict of Interest}

The authors report no conflict of interest.

\section{References}

1. Deogade S, Gupta P. Window impression technique: a prosthetic approach to flabby ridges. Annals Prost \& Res Dent 2017;3: 132-135.

2. Lynch CD, Allen PF. Management of the flabby ridge: using contemporary materials to solve an old problem. British dent J 2006;200: 258-261.

3. Allen PF, McCarthy S. Complete dentures from planning to problem solving. London: Quinstessence Publishing; 2003. p. 48-51.

4. Chakarvarty K, Tomar SS, Tandan P, et al. Managing flabby tissues with different impression techniques: a case series. IJOCR 2015;3: 95-99.

5. Labban N. Management of the flabby ridge using a modified window technique and polyvinylsiloxane impression material. Saudi Dent J 2018;30: 89-93.

6. Pai UY, Reddy VS, Hosi RN. A single step impression technique of flabby ridges using monophase polyvinylsiloxane material: a case report. Case Rep Dent 2014: 1-6.

7. Sulistiawaty I, Dharmautama M, Machmud E, et al. Prosthetic rehabilitation using adhesive bridge and fixed-fixed bridge on the maxilla and telescopic crown overdenture on mandible. J Dentomaxillofac Sci 2016;1: 210-212.

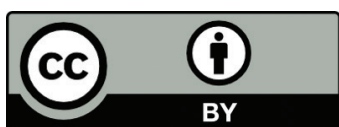

This work is licensed under a Creative Commons Attribution 